\title{
4 Tragedy and Historical Event
}

\subsection{Literature as Historical Event}

Literature occupies a variable place in its relation to history and reality, and to its own autonomy. On the one hand, the concept of literature has been defined, in the tradition that originates in Benjamin, as historical event. And, on the other hand, as Derek Attridge explains in The Singularity of Literature (2004), today we also "still talk about 'structure' and 'meaning', and ask what a work is 'about', in a manner that suggests a static object, transcending time, permanently available for our inspection" (Attridge, The Singularity of Literature, 59).

As I have shown, Foucault attributes the evental capacity of literature precisely to its formal and material character - we could say, indeed to the very traits that had declared its autonomy. As we have seen, literature refers to reality through a formal incapacity: it is not capable of speaking of everything, and this shows that we can no longer declare that literature is a self-referential and ahistorical activity. This shift in Foucault's literary thought towards a politics of literature has its most visible consequences in his later years. Therefore, the literary thought of the later Foucault lies closer to the Benjaminian tradition, which he had begun to develop in his work, "L'extralinguistique et la littérature", dating from 1967 and 1968. We thus accentuate two conditions of literature: first, as per T.S. Eliot, that the corpus of literature is historical and variable; and second, with Terry Eagleton, that in the course of history, works can go from being seen as fiction to non-fiction, and vice versa.

Along these same lines, Attridge asserts that literature refers "potential possessed by a body of texts for a certain effectivity, a potential realized differently - or not at all - in different times and places. (Since the literariness of any given text may always emerge in the future if it has not done so in the past, this is a body with no determined limits)" (59). However, for Attridge, literature seems to be outside of history, in a paradoxical way, since it awards all its capacity for effectivity to its reading. Therefore, we cannot think the event of literature, its literariness, as being on the margin of reading and all reading is historical. The potentiality of literature is, for Attridge, therefore, ahistorical, whereas its realization in reading is historical.

Foucault, however, considers that the marginality of literary discourse is what allows it to echo events not assimilated by the discourses of power. So Foucault stops considering literature as a transgression of limit, and considers it the place where certain epistemic transformations of the history of thought take place. According to Foucault, all discourses cohabit in history, there is never an 
"outside of history", because these margins of discourse cohabit and define the history of what does not want to be seen. But he grants literature, moreover, another capacity: that of participating itself as discursive event, being the place that gives an account, for the first time, of certain historical events.

In this chapter, I will focus on three moments in which literature is discursive event, all related to classical tragedy, in Foucault's analyses of the 1970s and 1980s. These are found in his different analyses of Oedipus $\operatorname{Rex}^{25}$ and attention to the tragedies of Euripides in his genealogy of the concept of parrhesia in the classical era, mainly in Discourse and Truth (1983).

\subsection{Parrhesia: Between Emancipation and Danger}

Foucault devoted his last three lecture series at the Collège de France to the study of the interweaving of life and truth through parrhesia: Subjectivité et vérité [Subjectivity and Truth] (1980-1981, published 2014 in French), Le gouvernement de soi et des autres [The Government of Self and Others] (1982-1983, here quoted from the 2010 English edition) and Le courage de la vérité [The Courage of the Truth] (1983-1984, here quoted from the 2011 English edition). In the first of these, Foucault focuses on the study of the relations between truth, subjectivity and others, giving particular attention to questions related to desire (aphrodisia) and the law. This work is in constant dialogue with the History of Sexuality (I-IV). However, the last two lecture series evolve toward an aesthetics of existence in which the care of the self has direct consequences in the care of others. We could say that Foucault shifts from an ethical concern, the care of the self (epimeleia heautou), toward a political question, "the government of others". The most immediate consequence of this shift is that Foucault considers that the path toward politics should always be guided by a concern of the citizen as subject of self, along similar lines as the ethical and political thought of Hannah Arendt in The Human Condition (1958). The subject, therefore, must attain their emancipation in order to freely exercise the use of their word as citizen in dialogue, and always mediated by the other. In fact, Foucault states in The Courage of the Truth, "in ancient culture, and therefore well before Christianity, telling the truth about oneself was an activity involving several people, an activity with

25 These analyses are carried out in the second of the Río de Janeiro lectures collected in "The truth and the Juridical Forms", in "The Knowledge of Oedipus", the lecture delivered in Buffalo in 1972, in the lesson of 28 April given in Brussels and collected in Wrong-Doing, TruthTelling (1981), and finally in the lessons of the 1982-1983 course in the Collège de France titled The Government of Self and Others, particularly in the lesson from 19 January 1983. 
other people, and even more precisely an activity with one other person, a practice for two" (5).

In this way, Foucault responds to his own concern for the problem of the social subject's freedom conditioned by the relations of power, with an opening from ethics and the emancipation of the care of oneself. This is to say, it will no longer be a figure of authority who determines the emancipation of subject citizens, but the subject in the framework of a relation of trust who will make their emancipation possible.

This shift and the affirmation that it is the ethics of the care of self which makes the subject a free and emancipated citizen are to be found in the path that Foucault traces from his works on Oedipus to the tragedies of Euripides, as will be seen. Thus the classical tragedies are not only the stage on which he gives an account of a series of new ideas regarding classical judicial systems and their transformation in the texts of Sophocles and Euripides along the lines of the politics of literature that we have been defining; they are also the stage where Foucault formulates the traits of a political subject.

In the framework of his work, Foucault locates his writing on the genealogy of parrhesia as part of his concern for the coercive modes of truth-telling of the modern subject in his same work, as it derives through the concern that the coercive obligation of the subject's speaking truth through institutions had marked in modernity. And he also shows the political origin of the term. Thus parrhesia is a vehicle for articulating his concerns about the dominated subject in modernity and, in turn, a mode of analysing modes of interpellation, of production of subjectivities, through the emancipation of the subject. It is not for nothing that the concept of parrhesia is translated to Latin, not without problems, as "libertas".

In my study, it is particularly relevant that this concept appears for the first time in the Greek literature of Euripides, proceeding to spread throughout the Greek literary world of antiquity from the end of the fifth century BCE. Etymologically, parrhesia means "to say everything" (pan-rhema), and it referred to the capacity to speak frankly and freely. This speech-oriented concept emerged in association with Athenian democracy and links truth with belief or trust. ${ }^{26}$ Foucault's works follow the historical development of parrhesia from its first usages in Athenian democracy through its transformation under autarchy, its use in the classical philosophy of Plato, Aristotle and the Cynics, up to its

26 Consider here the difference between the parrhesia that emerges linking the concept of citizen and the concept of subject, regarding the subject of modernity, for which, as per Descartes, knowledge is a mental activity which is accessed through evidentiary doubt. 
use in primitive Christianity and Christian pastorals. This word runs through the foundations of Western civilization. Foucault summarizes the characteristics of parrhesia thus:

parrhesia is a kind of verbal activity where the speaker has a specific relation to truth through frankness, a certain relationship to his own life through danger, a certain type of relation to himself or other people through criticism (self-criticism or criticism of other people), and a specific relation to moral law through freedom and duty. More precisely, parrhesia is a verbal activity in which a speaker expresses his personal relationship to truth, and risks his life because he recognizes truth-telling as a duty to improve or help other people (as well as himself). In parrhesia, the speaker uses his freedom and chooses frankness instead of persuasion, truth instead of falsehood or silence, the risk of death instead of life and security, criticism instead of flattery, and moral duty instead of selfinterest and moral apathy.

(Fearless speech, 19)

Parrhesia is thus for Foucault the expression of the potentiality of language and, therefore, it creates an effect that relates it to performative utterances and moves it closer to criticism - or what, in Michael Hardt's interpretation of parrhesia, is militancy ("The Militancy of Theory") - insofar as it has effects outside of language itself.

What makes a statement characteristic of parrhesia is precisely that it opens itself to risk. Similarly, in the performative utterance, the subject of enunciation is important. Status is indispensable for the execution of a performative utterance, although it might matter little whether there is any personal relationship between the speaker and the utterance itself, that is, a relation of sincerity between the performative utterance and the one who utters it. In parrhesia, by contrast, and in what it does, not only is such indifference not possible, but there is always a formulation of the truth occurring on two levels. A first level is that of the statement of the truth itself (at this point, as in the performative, one says the thing, and that's that). The second level of the parrhesiastic act, the parrhesiastic enunciation is the affirmation that in fact one genuinely thinks, judges and considers the truth one is saying to be genuinely true (parrhesiastic act, affirmation of the affirmation).

(Foucault, The Government of Self and Others, 64)

However, as Foucault explains, the discourse of parrhesia, unlike performative utterances, takes place outside of a context that guarantees that the saying effectuates what is said, and carries with it a risk and an opening of the situation that has nothing to do with the institutionalization of performative utterances. Thus, while in the performative utterance the status of the person speaking is important, in the parrhesiastic act, what endorses the utterance is that the person speaking asserts their own freedom as a linguistic-political individual (65). Foucault says, "it is not the subject's social, institutional status that we find at the heart of parrhesia; it is his courage" (66). The effects of the potentiality of language that democratic parrhesia represents have a political function that for 
Foucault entails a transformation of the social-political order in a given community: Veridiction that produces a hiatus, an interruption and a transformation. And this use of the action of language, of a language that is the language of everyone, is a political practice that also causes an unknown and dangerous reaction for the person who utters it.

Yet the description of the historical uses of parrhesia enables us to trace two lines of continuity: one that is introduced through parrhesia as a political concept tied to the citizen-subject who utters it; and the second that follows the "other parrhesia", which refers to a bad use of the freedom to say everything and that, for us, will trace the status of a series of discourses in modernity, which is where literature and madness coincide.

According to Foucault, the term parrhesia can also be used in a pejorative sense. It is the comic playwright Aristophanes, who had ridiculed Euridipes in The Frogs, that makes us aware of this: "we find it used in a pejorative sense, first in Aristophanes, and afterwards very commonly, even in Christian literature" (Foucault, The Courage of the Truth, 9). It is important to consider that this pejorative use is precisely saying everything, but as "saying anything (anything that comes to mind)". Hence the other possible face of the parrhesiast appears, that of the "impenitent chatterbox, someone who cannot restrain himself or, at any rate, someone who cannot index-link his discourse to a principle of rationality and truth" (10). In texts from the 4th century BCE, says Foucault, the place of parrhesia as free and excessive saying with ambiguous effects seems to be reversed, and democracy comes to present itself as the place where parrhesia (truth-telling, the right to express one's opinion, and the courage to go against the opinions of others) will become increasingly impossible and in any case dangerous (35-36). Thus distrust is created around parrhesia.

Foucault finds one of the key examples of this distrust of parrhesia in Isocrates, at the beginning of the speech On the Peace (355 BCE, paragraph 13). Here he alludes to orators and poets who say everything about the gods, and whom the Athenians listen to with complacency. But, according to Isocrates, those who stand up to speak are in reality nothing more than drunks, people who act without reason, fools, in short. In this free speech of democracy, there are true discourses, false discourses, useful opinions and pernicious, harmful opinions; men dedicated to the city, foolish men, the good and the bad, all juxtaposed and intermingled in the game of democracy. And this is, he warns, when parrhesia is a danger for the city (36). True discourse does not overcome false discourse in democracy. What Isocrates is indicating is the principle of quantitative opposition or principle of scansion of the unity of the city, upon which moral, ontological and political inequality is founded. 
In order to exemplify this lack of separation and confusion that parrhesia causes in democracy, Foucault takes up the text that is falsely attributed to Xenophon: ${ }^{27}$ Constitution of the Athenians, a parody of the democracy that has descended from aristocracy. This text is a defence of the principle of political inequality (against Isegoria), namely, as Aristotle argues in his Politics: that by nature there are slaves for whom being governed by an authority is an advantage, given that not all people share of reason in the same way (principle of cognitive inequality) and, in the case of Pseudo-Xenophon, this lack of reason coincides with wickedness. ${ }^{28}$ The Pseudo-Xenophon distinguishes two types of government: on the one hand, the government of the most sensible and honest, in which the madmen (those who lack sense) are not allowed to speak, participate in the assembly or give their opinion, and what reigns in the cities is eunomia (good constitution, good governance). On the other hand, the great merit of Athens, says Pseudo-Xenophon with irony, is precisely that they have not given themselves the luxury of eunomia and have not prevented the madmen from entering the assembly. The merit of democracy is not having accepted such restrictions. The problem is that if the best citizens make the decisions, then they will only serve their own interests, whereas in democracy, those who make the decisions are the more numerous, not the best. And therefore they want what is bad, for them and for the city (Foucault, The Courage of the Truth, 42).

It is not only in Aristophanes and Isocrates that bad parrhesia and its relation with literature appears; we also find a discussion of bad democracy in Book VIII of the Republic. As Foucault explains, Plato describes this bad democracy as "all motley, fragmented, and dispersed between different interests, passions, and individuals who do not agree with each other. This bad democratic city practices parrhesia: anyone can say anything" (The Courage of the Truth, 10). We can find this same Platonic criticism in the famous dialogue, Ion. ${ }^{29}$ Recall that Ion was a rhapsodist committed precisely to being able to talk on any subject. Ion represents the midpoint between oral culture and the arrival of written culture.

27 Attributed to Xenophon, "Minor texts".

28 On the later relation between unreason and depravity, we find other texts by the author that abound in what would be the "dangerous subject". See The Lives of Infamous Men, among others.

29 One of Plato's first dialogues, it is dated to around 401 BCE, separated by only a few years from Aristophanes' The Frogs, which is dated to around 405 BCE. The two works coincide with a historical moment in which the confidence in democracy that was enjoyed in previous years was lacking. Plato cites Euripides as inventor of the adjective "magnetic", which would have appeared in the tragedy Oeneus, of which only fragments have been preserved. Some years before, Euripides created the homonymous tragedy Ion (413-412 BCE), a work that Foucault recognized as being entirely dedicated to the problem of parrhesia. 
The themes of Plato's dialogue, one of the founding texts of Western literary thought, mark the difference between good and bad literature, between inspired literature and doxa, but above all between rational knowledge, the knowledge of philosophers, and irrational knowledge, enthusiasm or rapture, which corresponds with inspired poetry. From this is derived the hermeneutic incapacity of the rhapsodists, because they were mere transmitters of a knowledge that they themselves did not understand. ${ }^{30}$ But there is another striking trait of this truth that is transmitted, which is not a technique (technē) but rather corresponds to a "divine force" (533d-c) and is incorporated into a metaphor by Plato. This is the metaphor of the "magnetic stone", in the explanation of which Plato cites Euripides himself:

[...] a divine power which moves you like the stone which Euripides called Magnet, but most people call Heraclean. In fact, this stone not only attracts iron rings but also puts power in the rings so that they also have power to do the same thing the stone does and attract other rings. Sometimes quite a long chain of iron rings hangs suspended one from another; but they're all suspended by the power derived from that stone. So too the Muse herself causes men to be inspired, and through these inspired men a chain of others are possessed and suspended. For all our good epic poets [...] are inspired and possessed, and so similarly our good lyric poets too. [...] [they] do not dance in their right minds. [...] And they tell the truth. For a poet is [...] unable to create until he becomes inspired and frenzied, his mind no longer in him.

(Ion, $534 \mathrm{a}-\mathrm{b})$

The traits of this poetic truth are, on the one hand, unreason, as has been made evident; but in a less evident way this truth is necessarily the truth of the many that make up the "chain" of all those rings. The metaphor of the magnetic stone is also the metaphor of a democratic community. The Platonic metaphor therefore succeeds in unifying the features of a truth that, from this point forward, will be separated from the capacity of all citizens to speak freely without social division between reason and unreason, remaining linked first to poetics and then, in modernity, to literature, as one of the founding works of modern literature, Don Quixote, demonstrates. Modern literature thus carries forward a part of the parrhesia that had been expelled from the political space in general and from democracy in particular. This parrhesia is that which permits one to speak to everyone about everything, upon which the democratic principle of equality of the word is thus founded.

30 In Phaedrus, Plato directs this same hermeneutic critique at writing itself, which lacks a "father" which would establish its proper sense. 


\subsection{Tragedy and Democracy: Oedipus, Ion and Cassandra}

There are those who have read in Foucault's recourse to the tragedy of Sophocles an outline of the changes that Foucault's own work underwent during this time. One such is José L. Moreno Pestaña, who, in Retorno a Atenas [Return to Athens] (2019), argues that although Foucault makes use of Oedipus Rex at both the start and the close of the sixties, his different interpretations are symptoms of his ideological shift (56). Sforzini, however, considers that, although we can observe a change in the points of interest in Foucault's reading of Oedipus, the interpretative outline remains the same. According to Sforzini, "Oedipus Rex is the expression of a symbolic process of revealing the truth, sealing both the assertion of a new 'human', secular knowledge (the investigation) and the elimination of tyrannical excess (the utopia of unity in the exercise of power and knowledge) of the political and cultural space of the fifth-century Athenian polis" (Scènes de la vérité, 223).

My objective here is to demonstrate, on the one hand, the evental capacity of tragedy, as I stated at the start of this chapter. On the other hand, I aim to show how the different readings of Oedipus Rex are in dialogue with and stand in opposition to those that Foucault provides of the tragedies of Euripides who, remember, was defined as one of the most "progressive" figures of the socalled Athenian Enlightenment. From Sophocles to Euripides, Foucault manages to show the different accounts that are given of Athenian democracy and the evolution of some of its fundamental values, principally that which consisted of being able to speak freely, or parrhesia. Lastly, I aim to establish a continuity between the veridiction of classical tragedy and modern literature through the principle of parrhesia as a veridiction of literature at the margin of reason.

As Foucault explains in Wrong-Doing, Truth-Telling, literature is event not because it is mimesis of a real action but because it represents the practice of truth-telling:

So this is how Oedipus Rex may serve not, once again, as a direct testimony of Athenian judicial procedure, nor as a direct testimony of its true history, but rather as the first dramatic representation of this relatively new judicial practice (relatively new at the time) that made avowal and all other regular procedures of avowal an essential piece of the judicial system. 


\subsubsection{Oedipus and Symbol}

Oedipus has become a great social and historical myth thanks to the impact of Freudian theory. Oedipus is, for Freudian psychoanalysis, the basis for explaining the structure of the subject. The updated reading of Lacan, and even Passolini's homonymous film from 1967, confirmed this reading of the Western subject. Hence the Foucauldian reading of Oedipus was simultaneously a critique of a way of interpreting the tragedy of Sophocles and a critique of the concept of the subject in psychoanalysis.

In 1972, the work of Sophocles had already attained new prominence following the publication of Anti-Oedipus: Capitalism and Schizophrenia, in which Gilles Deleuze and Félix Guattari show that Oedipus is not the secret content of our unconscious but the form of coercion that psychoanalysis attempts to impose in its cure of our unconscious. Oedipus is, therefore, an instrument of power, a certain mode of psychoanalytical and medical power that is exercized over desire and the unconscious. This argument is also developed in Foucault's work, but his interest in this tragedy has particular characteristics and a continuity with his work. On the one hand, Foucault focuses on separating desire from this "bourgeois family drama", as we have seen in his lectures on Sade and in The History of Sexuality. On the other hand, Foucault takes apart the modern myth of Oedipus, returning to the text of the tragedy in order to undertake a reading, through the text itself, that lifts literature out of its political impasse, as he himself had advocated, along the lines of his work on "bad literature".

To do this, Foucault takes up a line of research that reveals the relation between Greek tragedy and politics, and which had attained renewed prominence since the 1950s. ${ }^{31}$ Cornelius Castoriadis also worked extensively on these relations in his 1982-1983 university seminars, entitled La cité et les lois ["The City and Laws"], in which he states that the genre of tragedy depicts the ontological foundations of democracy, given that in democracy "there is no global view of the reality upon which correct politics can be founded, at best only partial views"32 (138-147). This definition of democracy can be recognized in the work of Foucault himself, which enables us to characterize his concept of "politics of literature”. Arianna Sforzini, who has analyzed in depth all the dramatic forms that appear in Foucault's work and their modes of performance in Les scènes de la vérité: Michel Foucault et le théâtre (2015), states that Foucault "will always

31 See the works of D. M. Carter in this regard: "Society and politics in post-fifth century tragedy" (2018) and "Tragic parrhesia” (2018).

32 My translation. 
strive to transform the power of the tragic as a constitutive rending of history in a modality of historical analysis capable of making a political theatre emerge at the roots of all forms of truth and existence" ${ }^{33}$ (47).

The first work in which Foucault focuses on Oedipus Rex is the lecture series that he gave at the State University of New York in March 1972, two years on from his lectures on Sade. The 1972 lectures, entitled "The Knowledge of Oedipus", are rooted in the relations between knowledge and power. The basis of the analysis and textual interpretation that he carries out are focused on the knowledge that converges there: the rhetorical and philosophical mechanism of the symbol, or "law of two halves". Foucault carries out a reading of the dramatic text for the purpose of determining how a discursive strategy gives an account of the change in the judicial procedure of inquiry, as opposed to divinatory procedure which was introduced in the sixth and fifth centuries.

Foucault also develops his second work devoted to Oedipus along similar lines. This work appears in the collection of lectures entitled Truth and Juridical Forms (1978), in which he studies the emergence of new forms of subjectivity associated with historical ways of establishing and telling the truth. In one lecture devoted to the topic of "Oedipus and Truth", Foucault analyzes tragedy as a discourse that is capable of depicting a historical event in all its complexity, both formally, through its dramatic structuring ("the power relations that permeate the whole fabric (plot) of our existence" [Foucault, Power, 17]), and thematically. Foucault is still interested in the relations between power and knowledge, and wishes to study the tragedy of Sophocles as representative "and in a sense the founding instance of a definite type of relation between power and knowledge [savoir], between political power and knowledge [connaissance], from which our civilization is not yet emancipated" (17). But he introduces something new to his interest in literature when he considers it, as I have mentioned, as a historical event:

The tragedy of Oedipus is, fundamentally, the first testimony that we have of Greek judicial practices. [...] The tragedy of Oedipus is therefore the history of an investigation into truth: it is a procedure of inquiry into truth that exactly obeys the Greek judicial practices of the period.

(Foucault, "The Stage of Philosophy”)

The psychoanalytical myth of Oedipus, says Foucault, collapses in the face of a complex that is "collective and not individual". Oedipus is the route Foucault takes to attain the analysis of the first forms of democracy in the Athens of Pericles. And his chosen place for analysing these relations comes from the

33 My translation. 
character of Oedipus, which is the first testimony we have of judicial practices. He uses a series of techniques which allow for discovery of the truth that questions the power of the sovereign, or sovereignty. "The tragedy of Oedipus is therefore the history of an investigation into truth." We even find in his reading a philological perfectionism, a returning to the meaning of the text in its historical context. This is why the nature of Foucault's work differs from Deleuze's: one is historical and the other theoretical.

According to Foucault, the procedure that governs the tragedy "exactly obeys the Greek judicial practices of the period". Thus, it needs to be established "what the judicial investigation of truth in archaic Greece consisted of", and for this reason Foucault also refers to the Iliad as "the first testimony" we have of the investigation of truth in Greek judicial procedure, both in the lecture "Oedipus and Truth" (Rio de Janeiro, May 1973) and in the Louvain lectures of 1981, gathered under the title Wrong-Doing, Truth-Telling.

In these texts, Foucault focuses on two elements. One is philosophical: anagnorisis, or the recognition through which the person who believed that they were ignorant realizes that they already knew, and the person who is ignorant becomes someone who knows. According to Foucault, in Oedipus this has two traits. First, it is a "reflexive" anagnorisis: he who searches is the object of the search. Second, anagnorisis is attained by confronting different types of knowledge: it goes from the knowledge of hearing to the knowledge of seeing; from the knowledge that questions the gods to the knowledge that is asked from right here while hearing what other have also seen (the witnesses); from the knowledge that proceeds from prediction to knowledge as testimony; from the knowledge that proceeds from the enigma of the knowledge that the gods conceal to the knowledge that makes appear the person who wants to be hidden. Oedipus is the bearer of the knowledge of the tyrant and, finally, Oedipus also represents the powerknowledge transgressor. Already in Wrong-Doing, Truth-Telling, Foucault had revealed the existence of this character. In the Iliad, a character appears whose task is to ensure that the chariot race between Antilochus and Menelaus is fair. This

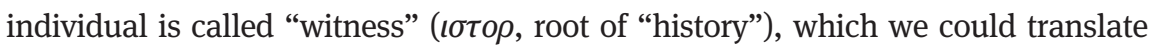
as "he who informs", but which Foucault translates as "one who is there to see". Although the existence of the witness is recorded in Homer's work, he is not made use of because there is no appeal to testify, only to a test by oath. Thus, if Antilochus had sworn falsely, it would have been Zeus who, punishing the false oath, "would have manifested the truth with his thunderbolt". This test of truth is a feature of archaic Greek society, Foucault explains, which is prior to the story. The memories of this procedure also reach Oedipus Rex, and later in the early Middle Ages. The truth of the oath passes for the truth of the subject, an exterior 
truth and, on occasions, it involves others who make guarantees of the trust in their word or who involve their adversaries in the challenge.

Along with historical investigations, Foucault adds another element of analysis of a narrative nature, which entails a deconstruction of the traditional concept of symbol. Thus, in Sophocles's tragedy, in order to pass from divine to human knowledge, one must achieve this knowledge through fragmentary reports that each witness provides and which complete the truth. Foucault's description and analysis of the symbol in Greek tragedy convert it into a mechanism of fragmentation as a tropological mechanism associated with democracy.

Foucault calls the method of investigating truth by way of the symbol in Oedipus Rex the "Law of Halves", because "the discovery of the truth is carried out in Oedipus by halves that fit and link together”. In Apollo's response to Oedipus's consultation, the god only answers half of the question concerning the curse and its cause, as he tells him that the cause is the murder of Laius, the former king, but does not say who the murderer is. To discover the name of the murderer, Oedipus appeals to the human double of Apollo on Earth, the prophet Tiresias, who replies in the form of a prophecy, "You're the one who killed Laius", but the dimension of the present is absent. In short, Foucault says, the "witness" to what really happened is missing. This second half of the story in the present is also told in the form of a game of halves. Jocasta is the first witness when she mentions that Laius died at the crossing of three roads, to which Oedipus responds with a recognition of the facts. Thus is the game of the two halves of the truth that almost complete the story of the murder of Laius. The story is completed when it is discovered that it was Oedipus who killed his father and married his mother. This second half of the story is completed by means of the joining together of several different testimonies: those of a slave who reveals to him that Polybus was not his true father, and a shepherd who tells him that Jocasta is his true mother.

In this way, Foucault undertakes a critique of the concept of symbol that Walter Benjamin developed in Origin of the German Trauerspiel. We can consider Benjamin's doctoral thesis to be a precedent of particular interest for Foucault's research, especially in these first studies of Greek tragedy.

In 1916, Walter Benjamin had developed the ideas for his work on German baroque drama, though it would not be published until 1928. In this work, he establishes the relations between tragedy and the art of governing. For Benjamin, however, tragedy showed this relation before the start of history and spoke of myth, whereas the baroque trauerspiel, through a discourse of history, had also shown the drama of all, not only of kings: "“whoever wants to write tragedies [...] must understand the art of government as intimately as he does his mother tongue.' [...] The sovereign represents history. He holds historical happenings in his hand like a scepter" (Benjamin, Origin of the German Trauerspiel, 46-48). This 
comes from ideas based on constitutional law. That is to say, the content of trauerspiel, its true object, is historical life as it was conceived in that period. As per Benjamin, this would distinguish it from tragedy, as the object of tragedy is not history but myth, and what gives tragic stature to the dramatis personae is not their rank (absolute monarchy) but the era, before history, in which their existence takes place: the heroic past.

Benjamin, with his interest in baroque allegory, was confronting the conceptualization of the symbol that had been developed by Germanists around the beginning of Nazi Germany. In this moment, the symbol represented unity and occupied a privileged place. For Foucault, on the contrary, modernity sank its roots in Greek tradition, which was part of history, but without recovering a lost unity. In order to take apart Benjamin's reading of the symbol as a mythological element, Foucault introduces the Greek symbol as emblem of his political reading of the text of Sophocles. For this he attends to the textuality of the work and its relation with history following Benjamin's proposals, but, conversely, he attributes to the symbol in Oedipus' tragedy an excess and quality of fragmentation by which it is no longer possible to attain a unity, as there the voices of all are mixed, not only those of emperors and heroes but also those of slaves and women. The reading of Oedipus Rex in these terms enables him to assert, from a narrative, tropological and political perspective, that literature and politics are interlinked from their origin:

What occurred at the origin of Greek society, at the origin of the Greek age of the fifth century, at the origin of our civilization, was the dismantling of that great unity of a political power that was, at the same time, a knowledge [...] We witness that long decomposition during the five or six centuries of archaic Greece. And when classical Greece appeared Sophocles represents its starting date, its sunrise - what had to disappear for this society to exist was the union of power and knowledge.

(Foucault, Power, 31-32)

Therefore, the symbol also represents resistance to divine power, which according to Foucault is shown in the distrust of the knowledge of the diviner both in his formulation of the prophecy and in his attempt to escape fate. Upon hearing the oracle, Oedipus undertakes an investigation that confirms that the oracle was correct, and that this truth and the one to which a slave was witness are the same. The slave is the only one who knows as much as the god and his seer. For this reason, the proliferation of the tragedy's voices are reassembled in an asymmetrical mix in which Foucault considers, "Can we say that the slave's silent gaze and the all-seeing sovereign's word 'symbolize' each other?” (Foucault, Lectures on the Will to Know, 238).

As opposed to mythological knowledge, here the oracular truth must be completed by human truth. Truth is split into two halves that, in turn, fragment into others. But what makes it possible to unite all the fragments of this truth is 
the coinciding of both truths, the human and the divine, which coincide in a single, same truth, whether formulated as an enigma by the gods and seers, or as the testimony of a slave. There is a hierarchy among those that speak, but there is also a shift in the modes of knowledge: from the ear of the gods and the seer to the eyes of the witnesses, and in the middle, Jocasta, who tells what she heard from what the messenger had seen. Oedipus himself is a symbol, made up of "excessive" halves (the son is also the murderer of the father, he is the son of Laius and also of Polybus, both husband and son, and so on). But he also reveals duplications in his speech, as when he says two things at the same time. He is the figure of the double. ${ }^{34}$

The story responds to a fragmentation of halves, in terms of form and plot, as a puzzle of halves that have to be put back together in order to "form the whole pattern of the story" (Foucault, Power, 22). Thus the technique of the Greek symbol is redefined by Foucault:

an instrument of power and its exercise whereby a person who holds some secret or power breaks some ceramic object in half, keeping one part and entrusting the other to an individual who is to carry the message or certify its authenticity. By fitting these two parts together it is possible to verify the authenticity of the message, that the continuity of the power exercised. Power manifests itself, completes its cycle, maintains its unity by means of this little game of separate fragments of the same whole, a unique object whose overall configuration is the manifest form of power. The Oedipus story is the fragmentation of that token, the possession of which, complete and reunified, authenticates the holding of power and the orders given by it.

Sophocles's tragedy is, therefore, a rhetorical instrument as well as a political and religious one. And the achievement of this triple structure is that it functions, in turn, as a strategy for the formation of power. This structure entails, moreover, a series of consequences in its functioning: the shift in the assembling of the halves, first the level of the god and his representative, the seer, then leaving in the centre the testimonies of Oedipus and Jocasta, and, lastly, the testimonies of the slave and the shepherd are, however, those responsible for "pronouncing the final truth and providing the final piece of evidence" (23).

34 Foucault has paid special attention to the double in his pieces on literary thought in the 1960s. The double is a verbal form that acts as a figure of thought and as a political figure at the same time, which opposes dialectical synthesis as unity. In the book that Deleuze devotes to Foucault, he echoes this figure of thought that, according to Deleuze, obsessed Foucault. For a deeper examination of the literary thought of early Foucault, see Azucena G. Blanco El logos doble [The Double Logos, 2006]. 
In this analysis, Foucault also examines the different "mechanisms of truth-telling and the form in which truth is told" depending on who does it. Thus, when the truth is stated by the god and the seer, it is done in a time belonging to prophecy and a magical religious gaze, "the eternal and omnipotent gaze of the sun god and the gaze of the soothsayer who, though blind, sees past, present, and future" (23). But the gaze is also possible at a lower level; since the two slaves testify to what "they have seen", it is the "gaze of the witness". This gaze, which was ignored in the Iliad, here takes centre stage, history and gaze coming together as in the etymological meaning of istor (history, and he who sees, the witness). Thus we move from the future discourse of the prophecy to the retrospective discourse of history: "we can say that the entire Oedipus play is a way of shifting the enunciation of the truth from a prophetic and prescriptive type of discourse to a retrospective one that is no longer characterized by prophecy but, rather, by evidence” (23).

\subsubsection{Alethurgy and Parrhesia: From Oedipus to Ion}

In the 1980s, Foucault develops his work on truth-telling, or veridiction. The relation between tragedy and law was, at this point, a common place, as Foucault himself states ("everyone knows that in Greek tragedy, the theme of representing law - of the foundational representation of law - is essential” (Foucault, WrongDoing, Truth-Telling, 58)); and theatre itself, says Foucault, from its origin until the eighteenth century, also had the function of giving space to the debate on law. Thus all of his work of the period on theatre deals directly with this relation, but added to his previous interest in what he called "theatre of truth". Remember that in "The Stage of Philosophy" (1972), the author had already spoken of his interest in "describing the way in which Western men have seen things without ever considering the question of whether it was true or not; trying to describe the way in which they themselves have organized, through the game of their gaze, the spectacle of the world" (150). Therefore, it is evident that his interest in the vagueness of the "gaze" of theatre directly concerns his critique of phenomenology, but years later, his words acquire another added meaning, which involves the theatre and its forms directly in his philosophical project on truth-telling and classical parrhesia. Hence in these years the shift takes place from his interest in knowledge-power relations to the forms of veridiction. This change is similarly 
evident in his lectures on Oedipus, and which in the 1980s was in contrast to the lectures he gave on the tragedies of Euripides in the last years of his life. ${ }^{35}$

In 1981, Foucault gave the lecture series at the Catholic University of Louvain that has been published under the title Wrong-Doing, Truth-Telling. In these lectures Foucault proposes analysing the relations and the mutual implication between the true word and the just word. Foucault shows how the forms of expression of truth or of access to truth are transformed into three historical moments: in the Greek prelaw, in which the archaic forms are established, a mode of relation between the true (alethes) and the just (dikaion) based on the oath, going as far as the confession. He takes up the reading of the stage of the Iliad and Oedipus Rex to show the problem that encloses the title of the lectures, namely: that the accused is, at the same time, the guilty and the bearer of truth who has to confess in a liturgy of truth or alethurgy the confession. Oedipus, Foucault says, is also a scene of judicial confession of agonistic structure, in which there is an accused and that accused is the bearer of the truth, the same truth that will end up condemning him and freeing him at the same time.

Thus are the instruments themselves of inquiry organized. And this inquiry is also carried out in a way that is juridically very recognizable. In Oedipus Rex, the chorus is the jury. After Tiresias, who appears as a witness, Creon makes a declaration. Creon is not a witness, but rather comes to complain because Oedipus has accused him slanderously. Oedipus then accuses him of "witness bribery", and in effect it is this that Oedipus reproaches him for. He reproaches him for having bribed the witness who should be the oracle and whose meaning he has falsified in transmitting it. The last scene, in which the truth emerges, is a scene of judicial testimony, of inquiry: questioning, obtaining confession through threat, with the threat of torture until it is achieved. The general framework of the play is, therefore, a perfectly recognizable procedural framework.

The importance of Oedipus is underlined again in its nature as historical event, insofar as Oedipus is the first foundational representation of law that directly shows the issue of the truth-telling of the accused, of this contradiction that means that the accused must at the same time be the bearer of the truth of his own crime. In the tragedy, this aspect appears represented by the fact that Oedipus is the judge and the accused at the same time. Foucault shifts his interest in the relation between law and the Oedipal tragedy from the fragmentary symbol - not

35 In particular, in lectures he gave at Grenoble (1982) and Berkeley (1983), collected in Discourse and Truth, and in the Collège de France lecture series (1982-1983), The Goverment of Self and Others. 
unitary as it had been read traditionally - that represented Athenian democracy as voices that converge on a truth enunciated by many, to a concept of archaic power that would be the same that explains the double function that the enunciation of truth fulfils in our culture. Furthermore, Foucault says, the reading of Oedipus Rex is the opportunity to analyze a crime under its double aspect of "infraction of fundamental law and a religious sullying - two aspects that are inseparable in ancient Greek thought and culture" (Foucault, Wrong-Doing, Truth-Telling, 59). A problem of how to give room to family law within the law of the city, how one confronts the other and how to coordinate them.

Hence Foucault analyzes the tragedy using elements from Aristotle's Poetics. Recall that, as we have already seen, Foucault had made a critique of the concept of classical fable and verisimilitude in "L'arrière-fable" [1966, "Behind the Fable"]. He concluded that the relation between the fable and verisimilitude is determined by the "mythical possibilities" of culture - that is, that the verisimilitude of a narrative depends on what a society is prepared to accept as credible, and therefore this relation is historical and does not belong to the structure of the narrative. It thus opens the way to a relation of literature with the world, and completes its interrelational character with history, through its defect or finitude, and its need to refer to the world to be completed. Literature thus developed its extralinguistic nature, given its verbal limitation and a cultural definition of the concept of verisimilitude. Foucault also responds to the, once again, Aristotelian distinction between poetry and history.

Here Foucault examines two other concepts that structure the tragic fable, both elements directed at achieving catharsis. These are peripeteia and recognition or agnition, which, according to Aristotle, "should grow naturally out of the plot of the story, so that they come about, with necessity or probability, from the preceding events. There is a great difference between something happening after certain events and happening because of those events" (1452a 20). Two of the elements on which, as per Aristotle, tragedy is based, are peripeteia and recognition. Peripeteia is the narrative strategy that inverts the fortune of the characters and changes happiness into unhappiness, or luck into misfortune; and recognition consists of the revelation of the real identity of a character previously unknown or ignored, which is the change from ignorance to knowledge.

Aristotle explains the concepts of peripeteia (reversal), agnition (discovery) and pathos (suffering) with the example of Oedipus: "in Oedipus, a messenger comes to bring Oedipus good news and rid him of his fears about his mother; but by revealing his true identity he produces the opposite effect" (1452a 25), and "discovery [agnition] takes its finest form when it coincides with reversal [peripeteia], as in the Oedipus” (1452a 30). 
These processes structure the "fate" of Oedipus, which he himself confronts with the instruments of inquiry. This inquiry is juridically recognizable as part of a trial in which the chorus is the jury while the different characters make their declarations. And the last scene is, then, that of the appearance of the truth - anagnorisis - a scene of a real interrogation, in which a confession is obtained through the threat of torture.

However, according to Foucault, in Oedipus Rex, there were two types of anagnorisis, two recognitions. There is an individual anagnorisis, through which Oedipus learns his own truth, and the other axis, the establishing of the truth, before the eyes of the chorus, which acts as jury. Although the two are related, if Oedipus seeks the truth it is so the chorus may recognize it: that is to say, so that the citizens, the assembly of the people who constitute themselves as the judicial authority, may discover and establish the truth and, ultimately, validate it (Foucault, Wrong-Doing, Truth-Telling, 63).

This manifestation of the truth, or alethurgy, is spoken through the dialogue of the characters. According to Foucault, this truth, so difficult to learn for Oedipus, is nevertheless said fully at least three times. The first time it is spoken by two characters who, when speaking together, produce the truth, namely Apollo and Tiresias. Apollo states why there is a plague and Tiresias says who is guilty. This is the first manifestation of the truth, the first veridiction, which is neither accepted nor legitimized. The second production of the truth is also the work of two characters who make the truth complete between them: Jocasta and Oedipus, who between each other name the totality of things that make it possible to recognize the latter as the husband of his mother and the murderer of his father. This second alethurgy is also left pending resolution and is not accepted, because an element of uncertainty remains. Finally it is the third time the truth is spoken, with a new pair of characters, that it is accepted at last, is validated and brings about the judicial and dramatic effects that are expected of it. This third pair to produce alethurgy are the messenger from Corinth and a slave, the shepherd from Cithaeron. They too will produce the truth through the combination of elements in their knowledge. Hence we have: Apollo and Tiresias at the divine level; Oedipus and Jocasta at the level of kings and chiefs; and the messenger and the shepherd at the level of slaves and servants. And it is this last pair who produce the alethurgy that neither the kings nor the gods had been able to produce because they had not been recognized by the judicial institution. First, the truth of Apollo and Tiresias is not accepted, because both are independent of the judicial order and their knowledge comes from vision (Apollo sees all, and the seer has timeless vision), it would not have been possible to obtain a confession or testimony, and so the judicial machinery does not work. Their knowledge is outside of the law, it cannot provide proof and is outside of history. 
The second alethurgy is produced between Jocasta and Oedipus but also lacks judicial validity. Because Jocasta does not know truthful testimonies, she only knows public rumours, she is made to think that several people killed Laius, and for this reason Oedipus believes that he has been able to escape the fate of the gods (Foucault, Wrong-Doing, Truth-Telling, 70). Foucault finds the key to understanding why Oedipus did not understand the truth that was shown to him in the chorus, which gives a warning on tyranny. The chorus begins in a fairly strange way with a curse against tyranny and excess, the arrogance of tyrants who play at the height of their fortune and subsequently fall to the lowest depths (71). The problem is that the truth and the knowledge of Oedipus come from the tyrannical powers that he possesses: power, sovereignty, and the crown. The negative criticisms of Oedipus from the mouths of other characters outline the traits of tyranny: "You're wrong; you identify with this city where you were not born, you imagine that you belong to this city and that it belongs to you; I belong to this city as well, it's not yours alone" (Foucault, Power, 28). Oedipus shows some of the traits of historical tyrants, such as Cypselus of Corinth, who also considered himself owner of the city and used to say that Zeus had awarded it to him. And like Cypselus, Oedipus did not attribute importance to the laws either and replaced them with his orders, with his will. When Oedipus substitutes the law for his will, his fall from power begins. Oedipus, says Foucault, is "a figure that is clearly defined, highlighted, catalogued, characterized by Greek thought of the fifth century - the tyrant" (28). This tyrant is characterized, moreover, by a type of knowledge because his power is associated with a superior knowledge: Oedipus is sophos, and he is also heuriskein, he who finds. He also uses the verb oida, which means both to know and to see. Oedipus is the man of the gaze until the end, he is the man who wants to see with his own eyes, by himself, without depending on anyone: it is the autocratic knowledge of the tyrant who by himself can and is able to govern the city. Oedipus is the man of excess, who knows too much and is too able. "He is the man of excess", he is the tyrant. Oedipus has accumulated too much power and knowledge, it is an excess in the form of authoritarianism and reaches the sexual sphere as excess too. His excess is, finally, an atrocity, a monstrousness of power-knowledge.

Besides, this techne technes, supreme art and supreme knowledge, is according to Foucault a question concerning power as technical knowledge, a crucial question in the debates of the Sophists, Socrates and Plato. The question is whether the knowledge of power is learned or not. The expression is also used in Christian pastoral to designate the way - the art, the technique - that makes it possible to govern souls and lead them to salvation. In tragedy, power appears represented in its two facets: dynasteia, which is the capacity to exercise power, and tyrannis, tyranny, as the personal exercise of power. Oedipus 
represents this exercise of power, and his technē is inquiry, ${ }^{36}$ the art of discovery that makes it possible to go from the past to the present. And this art of governing in the tragedy of Sophocles is associated with tyranny, in its ambiguous meaning of the era: tyranny is in part the exercise of personal power by someone who has the status of hero, someone who, moreover, has a privileged relationship with the gods that enables him to give his laws to the city; but the tyrant is also the man of excess, the man of abuse, someone whose use of power goes beyond moderation and rule.

The third alethurgy, Foucault explains, is what makes it possible for everyone to learn the truth, and it is the representation of a "true judicial interrogation according to the rules". Two characters come face to face: the messenger, who appears spontaneously to announce the death of Polybus, and the shepherd from Cithaeron, who had been summoned by Oedipus. And from this confrontation the truth will emerge. This interrogation makes it possible to confirm identity (first anagnorisis), by which the shepherd who took the child recognizes Oedipus (Foucault, Wrong-Doing, Truth-Telling, 77). He is then interrogated about what he did with the child and what happened. And although he is reluctant to answer, the servant is compelled to speak (unlike the god and the seer). Oedipus even goes as far as to threaten torture. The answer of the servant is marked, from the grammatical point of view, by acceptance through the autos: it is no longer secondhand testimony (second alethurgy). And it is uttered with oneself speaking truth: "Yes, I am the one, autos ...”. And the confession: it was I who did not kill him autos (79). This is where the juridical acceptance of the confession is produced, when the chorus accepts it as indisputable truth. And it is an indisputable truth because it is pronounced with the autos (I say, I saw, I did) (79). Only then does Oedipus know and recognise himself as the one he did these things. Although the truth had been said before, he only recognizes it when a confession, an avowal, is made, and someone utters "I" in relation to all his crimes (79-80).

Thus we find, at the origin of democracy and Western law, the connection of the truth with the subject. And it arises as a critique of a truth that remains at the margin of the community (represented by divine truth) and of an imprecise truth. The truth of the person that speaks must be implicated in the enunciation of the truth of the facts. It is the precedent of the "I confess". The Greek judicial system only admits a truth formulated by a citizen, free or slave, who

36 According to Foucault, this technique is related, in turn, with two others: medicine and the art of navigation. This trilogy: the art of ruling, the art of healing, and the art of navigating, will be fundamental in all thought, all the subject matter of political thought, practically until the $17^{\text {th }}$ and $18^{\text {th }}$ centuries in the West (75). 
keeps within the limits of justice and law. For this reason, a sophron power is also necessary, a wise power that is capable of listening to one's people.

Foucault interprets the figure of Oedipus in this way. Oedipus is the tyrant who investigates to find a truth in a narrative (fable) and judicial (representation of a trial) structure, based on the two techniques that Aristotle describes in his Poetics: recognition and change of fate. The first technique corresponds to alethurgy, which, as Foucault explains, manifests in three instances, but the only one that is valid is that which makes use of the testimony of a witness in first person. The manifestation of the truth of the gods and what was not founded on reliable testimony are left aside. But Oedipus is also the representation of an excessive power that is incompatible with democracy; he is the tyrant. Oedipus believes that he will be able to escape human law and the decrees of the gods, and it is there, in that excess, that his government presents itself as an abuse of tyrannical power. The confession is therefore established as judicial practice in classical Athens: "it seems to me that it is interesting to see how avowal introduced itself with such solemnity into something as culturally and politically important as this ritual representation of law that the city of Athens gave itself' (Foucault, Wrong-Doing, Truth-Telling, 80). It is the legitimate production of truth that is juridically acceptable and that is accepted by the chorus, not as prophecy nor as deduction from circumstantial evidence, but truth constructed in the form of the interrogation of eyewitnesses who end up compelled to testify what they themselves saw, said and did. But as Foucault had previously explained regarding the tragedy of Sophocles, in accordance with the theory of the symbol, there is still a correspondence between divine and human knowledge, between the truth of the god and the truth of the shepherd. "They say the same thing, they see the same thing, but not with same language or with the same eyes" (Foucault, Power, 24). This correspondence is what defines the tragedy and establishes "a symbolic world in which the memory and the discourse of men are like an empirical margin around the great prophecy of the gods" (24).

Foucault had already argued, in the Brazil lectures, "Truth and Juridical Forms", with the theory of the correspondence of halves and symbol, that Oedipus is the man of knowledge who has seen and not the man of the unconscious who does not know (oida means knowing and having seen at the same time) and who is concerned with power. For Oedipus, says Foucault, power is what is important, he fears losing his own power. However, Oedipus will represent the figure of the good tyrant because, even though he wanted to run from his fate - and thus to achieve nothing except to condemn himself - he rejects the prophetic and oracular form of alethurgy. And it is even thanks to him that the city will be able to save itself in an auto-immune act. In this sense, Oedipus was necessary for the truth to appear, for the regular form of the judicial machinery 
that is capable of producing truth to be established. But now the judicial machinery that he himself has introduced eliminates him as though he were superfluous - as would be done to the Officer of the machine in Kafka's story, "In the Penal Colony", which carved the law into the skin of the condemned, and, finally, into the Officer's own. And that truth that saves the city is the same that condemns Oedipus. In one single speech, Oedipus saves and condemns, and lays the base upon which Christian alethurgy would be developed.

Lastly, we will look at the last analysis of the tragedy of Sophocles, which appeared once more in his Collège de France lecture, The Government of Self and Others. ${ }^{37}$ However, here it appears in contrast to another group of tragedies, by Euripides, particularly Ion. Euripides is the great tragedian of Athenian democracy, and in his writing we can see the evolution of the concept of parrhesia, from its positive meaning tied to the birth of democracy, to the criticisms it received in democracy's crisis. ${ }^{38}$ In The Courage of Truth, the last lecture series he gave at the Collège de France, in the lecture of 19th January 1983, Foucault made a structural comparison between Oedipus Rex and Ion. The contrast between the two tragedies was important for Foucault to make a wide representation of the ethical development of a concept of political origin, as parrhesia is, and its relation with the different stages of Athenian democracy.

We have seen that Oedipus represents the figure of the good tyrant because, in some way, he is capable of sacrificing himself for the common good in an exercise that I have considered autoimmunity. Foucault analyzed Oedipus Rex in Wrong-Doing, Truth-Telling and showed the result of the confession of the truth that was a forced truth - because the slaves who declare in the trial are compelled to confess, even under threat of torture.

Foucault returns to the question of the tyrant in the 1982-1983 Collège de France lecture series. But this time he does so to demonstrate the other side of Greek veridiction, parrhesia. The tragedy of Oedipus Rex showed a judicial process in which alethurgy was the result of a human and testimonial truth, which did not contradict the oracular truth but was independent of it. However, there is a moment in which the use of another veridiction, parrhesia, is necessary. Foucault refers, in the Lecture of 12th January 1983, to the scene in which Creon, Oedipus's brother-in-law, wants to tell him the truth, but Oedipus the

\footnotetext{
37 There is one last reference in his Collège de France lectures, 1984, in which he refers to the criticism that Diogenes makes of Oedipus as one who is not capable of correctly interpreting the signs because he is not capable of understanding the nature of his acts as something natural and not reprehensible, in accordance with the principles of nature of the Cynics.

38 I referred to this problematization at the beginning of this chapter. The crisis of democracy is associated with the problematization of the use of the free word, or parrhesia.
} 
tyrant does not want to listen to him because he is suspicious of his intentions. Creon states that he has no intention of taking his throne and that he only wants to tell him the truth of the oracle. According to Foucault, we will find this scene repeated - the scene in which the tyrant who exercises power, who is blinded by the exercise of power, and by whose side there is someone who dares to tell him the truth. This scene is, therefore, a scene of parrhesia. This first definition of parrhesia, along the lines that the other lectures will follow, is defined by textual identification, through textual examples of classical parrhesia, and differentiation, that is, comparing parrhesia with those modes of speaking that cannot be identified with it. Parrhesia, says Foucault, is differentiated from four other modes: demonstration, teaching, debating and persuasion (Foucault, The Government of Self, 52). To elucidate this first approach to parrhesia, Foucault compares this Oedipal scene with another from the "Life of Dion" in Plutarch's Parallel Lives. Parrhesia uses resources of these forms of truth-telling but is not the same as them. For example, Foucault says, it uses aphoristic utterances typical of demonstration, but dispensing with the rational structure that characterizes demonstration (53). It also uses resources of rhetoric, or in itself is defined as a figure of thought very contradictory in style because it has an element that is foreign to persuasion, which is conditioned by the purpose of convincing. In contrast, Quintilian would say that parrhesia is "the plainest of all figures of thought" because it is true libertas, he states in Institutio Oratoria. Foucault qualifies that when it is defined as a figure, "it is like the most basic form of rhetoric, where the figure of thought consists in not using any figure" (53). For this reason, parrhesia is not pedagogical either, and is located at the opposite pole of Platonic irony. "As if it were a veritable anti-irony," says Foucault, parrhesia is hurled straight at the interlocutor and thus it is closer to the methods of debate and argument. But there is a remarkable difference: there is no possibility for triumph in its structure. Creon does not confront Oedipus, he does not wish to convince or indoctrinate him. Parrhesia creates an effect in the interlocutor, but it can't be identified with the performative utterance either, as we have already seen. Therefore, although parrhesia shares enunciative modes that are typical of other discourses, it cannot be identified with them mainly because parrhesia is aimed at uttering a truth. Regarding discourse capable of speaking the truth, it will also be differentiated from other forms of saying the truth belonging to the classical period. Foucault again takes up the parallelism between the two tragedies - Oedipus Rex and Ion, which represent two different moments of the relation between parrhesia and democracy - in order to differentiate between the three forms of truth-telling: the oracle, the confession and the political discourse.

Foucault analyzes the structures of both tragedies and finds elements of inverted symmetry. To begin with, both characters live in the house of their father without knowing it. Ion lives in the temple of Apollo, unaware that the god is 
his father; and Oedipus lives in the house of his mother without knowing it. Similarly, Ion tries to kill his mother at a certain moment, without knowing who she is; while Oedipus commits patricide without knowing it. Furthermore, there is a more important analogy for Foucault, which concerns the mechanism of the search for truth. In both tragedies, the truth is tied directly to the question of who Oedipus is and who Ion is. And in both, the truth advances in halves symbol as dramatic construction - until being reconstructed. There is, however, an opposition between the drama of truth-telling in Oedipus Rex and in Ion: "In Oedipus, in fact, first of all it is Oedipus himself who brings truth-telling into play. It is Oedipus who wants to know the truth. As sovereign, and in order to restore peace and happiness in his town, he needs to know the truth" (Foucault, The Government of Self, 84); whereas in Ion, it is not he who seeks the truth but his parents. And both truths are also of a contrary nature: the truth of Oedipus is that he killed his father, thus leaving a hole in the sovereignty of the city that he himself has occupied, and it has led him to banishment from the city. In contrast, the truth of Ion is that he has two fathers: Xuthus and Apollo, and it is precisely this paternity that guarantees Ion the chance of living in the city as a full citizen and the free use of speech or parrhesia that it entails.

All in all, the fates of Oedipus and Ion are opposites: Oedipus, who is in power, had attained it through a series of adventures that converts him from the most wretched (abandoned child) to the most powerful. ${ }^{39}$ Oedipus is the one who, having been a hero becomes a king. He is the one who had healed the city, who had "raised it up" 40 (Foucault, Power, 27). Ion, in contrast, returns to his city to exercise a power given and legitimized by his revealed birth. Therefore, these processes of alethurgy in the two tragedies will have obverse consequences.

But not only do we find these obverse parallelisms between these two tragedies, to which Foucault devotes the most attention and analysis. According to Foucault, Ion is the Greek drama of truth-telling based on isegoria. ${ }^{41}$ This text

39 As Foucault had already explained, "This alternation of destiny is a characteristic trait of two types of figure: the legendary figure of the epic hero who has lost his citizenship and his country but who regains his glory after a certain number of trials; and the historical figure of the Greek tyrant from the end of the sixth to the beginning of the fifth century. The tyrant being the one who, after having several adventures and having reached the apex of power, was always under the threat of losing it." (Foucault, Power, 27).

40 Foucault explains that the expression "heal the city", associated with tyrants, refers to "lifting the cities up by means of a just economic distribution" (27).

41 In the Berkeley/Grenoble lectures, Foucault points out the antecedents in other plays by Euripides, which I can briefly summarize: The Phoenician Women, without parrhesia no power can be exercised; Hippolytus, without parrhesia there is no freedom (slavery); Bacchae, the parrhesiastic contract; Electra, the betrayal of the parrhesiastic contract; Ion, the truth is 
maintains a double relation with the truth. On the one hand, the dialogic truth appears as counterpart to the oracular truth, which was habitually expressed in an enigmatic language for men, being the language of the gods. Yet in this play, it stays silent, lies or gives a half-truth. Faced with the enigmatic truth of the oracle, the dialogic structure proposes a search for the truth through dialogue between the characters: between Xuthus and Ion, Creusa and the old man, and Creusa and Ion. This tragedy stages the search for a truth that belongs to men and that is constructed in the common dialogue of all the members of a community, even by those who do not have the right to speak in the assembly, such as the chorus of female slaves or the old man. Indeed, Ion wants to know who his mother is, but what we see in the dialogues is a search based on mechanisms of trial and error, a search for the truth by human means. And the reality of the facts is reached, namely, that Ion is the son of Creusa, through a composition of the truth that everyone had possessed a fragment of. What the play depicts is three forms of truthtelling: the oracle, the confession and the political discourse. The oracle cannot say what it really wants to keep silent: it is reticence to confess. However, Creusa confesses, in a clearly parrhesiastic speech, the rape by the god Apollo and the abandonment of her son in the same place where the facts took place. It is, therefore, men who must practise truth-telling.

On the other hand, we find the characteristics of a political truth, parrhesia, described. It depends on the right of everyone to speak in the assembly (or isegoria). Ion attains this political truth by means of that first truth made up of all the fragments of speech of the community. Only when Ion learns his genealogy can he claim his right to speak freely in the assembly, since in Athenian democracy this right to parrhesia depended on a right of blood. Thus a direct relation between the truth of the community and the expression of the truth itself of the political subjects is established. In parrhesia, as Foucault shows in his last lectures (The Government of Self and Others and The Courage of the Truth), the subject of the enunciation and the enunciandum concur, which is to say: "I am the one who thinks this and that" and takes on the risk (41). And, therefore, that truth-telling takes place in the "game" of life and death (43).

Foucault sums up the characteristics of parrhesia as "a kind of verbal activity where the speaker has a specific relation to truth through frankness ..." (Foucault, Fearless Speech, 19-20).

sought by human means; Orestes, political crisis in Athens. In a pejorative sense: "ignorant outspokenness/shameless”. Foucault here refers to the criticism of parrhesia as speech that stirs up the audience (it forms a part of exaltatio in rhetoric, the figure without figures): "putting his confidence in bluster and ignorant outspokenness, and still persuasive enough to lead his hearers into trouble" (170). 
However, as Foucault explains, the discourse of parrhesia, unlike performative utterances, takes place outside of a context that guarantees that the saying effectuates what is said, and carries with it a risk and an opening of the situation that has nothing to do with the institutionalization of performative utterances. Thus, while in the performative utterance the status of the person speaking is important, in the parrhesiastic act, what endorses the utterance is that the person speaking asserts their own freedom as a linguistic-political individual (Foucault, The Government of Self and Others, 65). Foucault says, "it is not the subject's social, institutional status that we find at the heart of parrhesia; it is his courage" (66). The effects of the potentiality of language that democratic parrhesia represents have a political function that for Foucault entails a transformation of the social-political order in a given community, very similar to the proposal that Jacques Rancière makes in The Politics of Aesthetics: The Distribution of the Sensible. It is veridiction that produces a hiatus, an interruption and a transformation. And this use of the action of language, of a language that is the language of everyone, is a political practice that also causes an unknown and dangerous reaction for the person who utters it. As Foucault states, rather than performativity, parrhesia stages a "drama" of the discourse, the analysis of which is the analysis of the discursive facts that show in what way "the event of the utterance affects the subject's mode of being" (68).

This double condition, of freedom and the danger of death, ${ }^{42}$ is represented in the tragedy of Ion by a classical metaphor: the double power of speech as poison and cure. Here we read this metaphor following the definition that Rancière gives in Mute Speech, that the metaphor joins and separates contradictory poetics, running a risky path between its own myth (book of hieroglyphs of spiritual life where the alliterations of things are inscribed) and its literal reality (Rancière, Mute Speech, 171).

As a free citizen of Athens, Creusa shares with her son Ion the double inheritance of parrhesia: Creusa possesses the two drops of blood of the Gorgon that Athena gave her father. Each of these two drops of blood, Creusa explains, has a power, one healing and the other deadly (Euripides, Ion, 78). These two drops

42 "In parrhesia, in one way or another both the statement and the act of enunciation affect the subject's mode of being and, taking things in their most general and neutral form, quite simply mean that the person who said something has actually said it, and by a more or less explicit act binds himself to the fact that he said it" (68). An analysis could be carried out of the different forms of dramatics of the truthful discourse: the prophet, the seer, the philosopher, the scientist. From the councillor, the minister, the critic and the revolutionary: I speak the truth in the name of the revolution that I am going to make and that we are going to make together. 
of blood function in the text as the same inheritance as parrhesia, which, in turn, remember, is a right of blood. With the poisonous drop, Creusa tries to murder Ion. But having been discovered in her attempt, it is through the dialogue caused by this failed attempt that Ion and Creusa learn the truth. Therefore, the line that develops the critique of parrhesia as dangerous speech is already in Ion, and it culminates in the separation of parrhesia from politics, as Foucault shows.

Due to this distrust, parrhesia and politics become separated, and the parrhesiastes is transformed in what Jacques Derrida calls the pharmakeus. In the analysis that Derrida applies to the Platonic dialogue Phaedrus in "Plato's Pharmacy", the pharmakon reconciles two opposing meanings: that of the cure and the poison at the same time (and no longer separated, as happened in Euripides's Ion: where Creusa could choose which word to use, because the drops were separate and each one had its function, as Creusa explicitly answered the old man's question).

In this text, Derrida shows that Socrates often takes the role of the pharmakeus in Plato's dialogues. In several dialogues, such as in the Symposium, they talk of power as an enchantment that Socrates wields through words. The Socratic pharmakon also acts as the most terrible poison, for its footprint invades the soul, transforming it (performativity). This demonic speech leads to philosophical madness and Dionysian raptures. On other occasions, it causes a kind of narcosis, as in Meno. Due to this duality contained in opposites, the use of the pharmakon can even turn against the person who uses it. And Socrates is first expelled to the limits of the city, and later sacrificed as a form of autoimmune protection of the city, in an attempt to recover the unity of the political body.

\subsubsection{Cassandra and the Herald: From Parrhesiastes to Pharmakeus}

In Euripides's tragedy Ion, we have seen a type of parrhesia that, in Athenian democracy, was tied to birthright, so the parrhesiastes was a free subject who was able to make use of his right to speak, equally free. Nevertheless, as we have seen, Euripides himself echoes the transformations and later criticism of this form of veridiction that was born with democracy. Thus I have considered that it is possible to read a sense of the concept of the parrhesiastes in pharmakeus, which alludes to the power that Socrates exercises through words, in its dangerous similarity to the persuasion of the Sophists and its power of transformation and performativity, typical of performative parrhesia. This speech is capable of leading to Dionysian madness, and even turns against the person who uses it. For those who use it, therefore, it is dangerous speech like parrhesia itself. 
But how is the transformation of parrheisa into pharmakea possible? This is only possible through the problematization of the concept, as Foucault shows. This problematization of parrhesia will entail its separation from democracy and, at the same time, its terminological appearance outside of tragedy, as Foucault shows in the Discourse and Truth lectures: "The word parrhesia is to be found throughout Greek literature from the end of the fifth century BCE, and you find it also in the patristic texts from the end of the fourth century, and from the fifth century CE. The word parrhesia appears for the first time in Greek literature in Euripides, and you find it still, dozens and dozens of times, in John Chrysostom, for instance, in the Christian literature at the end of the fourth century" (Foucault, Folie, langage, littérature, 39).

Ion, which dates from 418 BCE, presented a parrhesia that was tied to the citizens' birthright. However, from The Trojans onwards, we find a problematization of the concept through different means. On the one hand, a contrast is established between characters who represent the good use of the right to speak and others who abuse it. This leads to a new structure of dialectic opposition typical of the antilogy, which represents a criticism of the unitary composition of the symbol that we have seen in the tragedy of Oedipus Rex. Simon Critchley, in Tragedy, the Greeks and Us (2019), attributes this to the connection with Sophistry. And, on the other hand, in Orestes, one of Euripides's last tragedies, the term is used as an adjective and in a pejorative sense.

Regarding this last line of analysis, in the Berkeley lecture of 7 th November, 1983, Foucault refers to the pejorative uses of the word parrhesia from Orestes onwards. This play was written, or at least performed, in $408 \mathrm{BCE}$, barely two years before the death of Euripides and in a moment of political crisis in which the democratic institutions and regime were under debate in Athens. The word parrhesia goes from usage as a noun to an adjective. The doubts about parrhesia and its use in democracy coincide with inappropriate uses of it, in particular, people who use it for persuasive purposes.

However, with regard to the analysis of the characters who make bad use of parrhesia, the parrhesiastes confronts two character types: the tyrant and the herald. We have seen that Foucault distinguishes two types of tyranny: the tyrant who lets himself be counselled, as is the case of Oedipus; and the tyrant who punishes the parrhesiastes, revealing the danger of this truth-telling. But it is in Foucault's last analyses of the tragedies of Euripides, in which this other character, who holds no power at all, a character who depends on others - the herald.

The portrait of the herald in Euripides's Orestes (408 BCE) is clear: the herald makes use of a double discourse that wishes to wrap "malign words in beautiful phrases", a dishonest use: elexe dichomytha. The herald is described in Orestes as a person who uses rhetoric to disguise and who is "always leaping 
over to join those in prosperity". He is the friend of whoever dominates the city and is of high rank. The herald is not a slave, but he does not speak with freedom, he does not use parrhesia because he is "subservient to whoever is in power", he is a servant.

The herald tribe is like that - they're always jumping over to the side of the successful. Any man who has ruling power in the city is a friend of theirs. [...] a man stood up who can't keep his mouth shut, whose strength comes from his boldness - an Argive, but not from Argos - and forced himself on us, relying on bluster, ignorant free speech, persuasive enough to get them involved in some bad scheme or other.

(Euripides, Orestes, lines 884-931)

Foucault analyzes this tragedy, which represents the procedure of the trial for matricide of Orestes, ${ }^{43}$ told by the messenger. The figure of the herald is described by several characters in the tragedies of Euripides. All these characters share a common trait: their conditional freedom. They are characterized as subjects who are not completely free: "of course, he is not a slave, but he is not independent, he is dependent on people more powerful than he is. The Greek text says he is hupo tois dunamenois ōn (under the power of powerful people)" (Foucault, Discourse and Truth and Parresia, 101-102). This character is always in opposition to others who represent traits of a correct use of parrhesia. In Orestes, the herald opposes the parrhesiastes as a figure who works his own land with his own hands:

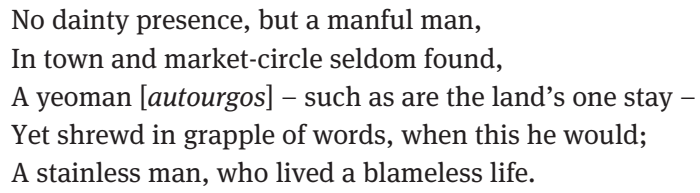

(Foucault, Discourse and Truth and Parrhesia, 101)

Foucault also refers to other tragedies by Euripides, The Suppliants and The Trojan Women. In the former, the scene contrasts the figure of the herald with that of the free city, without a tyrant: “'Who is the king in Athens?' Theseus replies, 'Well, you will not be able to find any king, because there is no turannos in this city, this city is free, that means that in this city, wealthy and poor people are equal'" (102).

Then begins a digression on the question of which is the best form of government, tyranny or democracy. The herald praises the tyrannical regime or, at

43 As in Oedipus, in Orestes it is a separation between the interests of the city and the right of family. 
least, makes a very harsh and detailed criticism of the democratic regime. Theseus's reply is a eulogy of Athenian democracy, in which he explains first that the laws are written down, second, that the rich and the poor have equal rights, and that in the assembly (ekklesia), every man is free to speak if he so desires. Those who speak in the assembly earn a good reputation and become the first among the citizens; the rest stay silent. And Theseus concludes: "Is there anything more egalitarian than that? Can equality go any further?" (Discourse and Truth and Parrhesia, 103). As can be seen, this democracy is characterized by equality and by the fact that everyone is able to speak. That is the objection that Theseus brings against the herald as a representative of tyrannical power. Then two other social types appear that correspond with the previous mythological figures. The first, as Talthybius, represents the bad orator, described as athuroglōssos, someone whose mouth is always open and who talks without stopping. As we can see, this is another type that is opposite to the parrhesiastes. The reply to the critics of parrhesia proceeds through the comparison of opposites, the didactic use of characters: between a good use of free speech or parrhesia, and a negative use of freedom of speech in the assembly. The notion of athurostomia is very close to the notion of parrhesia, but it is the negative version of this because the athuroglōssoi "cannot make any distinction between good thoughts and bad thoughts, and [...] they indiscreetly intervene in other people's lives" (105). But it is Plutarch's criticism that points out the real danger of this talking without stopping, incapable of biting their tongue - to use the metaphor of the mouth that is always open. The problem, Plutarch says, is that those who are athuroglōssoi do not give any value to logos, that is "to discourse, to reason, or to the reasonable discourse through which you can get access to truth" (105). Therefore, Foucault says, the athuroglōssos is the opposite to parrhesia and, in turn, is very close to it. Because the parrhesiastes shows wisdom, his discourse is sophos when he distinguishes what should be said and what not. The difference between parrhesia and athuroglōssos comes, moreover, from the content of their discourse. If the discourse ridicules ${ }^{44}$ and does not have content of a political or social nature, it is not considered parrhesia.

On the other hand, the direct emotional relations between the voice of the orator and its effect on the assembly is what is characterized by thorubos. Thorubos is a discourse that moves emotions and that is opposed to the reasonable meaning of an articulate discourse. But it is characterized more as an

44 Here we see a precedent of the brazen speech of the buffoon, for example, which is connected with parrhesia but cannot be confused with it. 
inarticulate noise that has a certain emotional effect on the assembly than as a discourse, strictly speaking. Then there is the last characteristic of this bad orator: confidence in the shameless freedom of speech, in amathei parrhesia. Here we find that this expression, which contains parrhesia as an adjective, is a repetition of the expression athuroglōssos. This citizen, this orator, in his role of assembly participant, "has parrhesia, but he does not use parrhesia as he is supposed to. His parrhesia is only a formal civic right" but he does not use this right well and in this case, lacks what is necessary to constitute good parrhesia, useful, politically positive parrhesia (107).

This figure contrasts with that of the good orator in Orestes. This man is described as morphē ouk euōpos, which means, as Foucault explains, that he has no physical presence - in other words, that not only is he distinguished discursively from the other orator but that even this is reflected in his physical appearance, because he does not use force to impose himself. But he is an andreios anèr, a courageous man, who is restrained, because he does not live from politics; he only participates in the assembly at important moments and for the taking of important decisions.

The fourth characteristic is that he is autourgos, a word that is translated as "yeoman", but which means that he is someone who does things by himself, he works by himself. He is not only a landowner but a landowner who works, not a poor peasant. The autourgos, Foucault says, appear represented as landowners who are concerned about the defence and protection of their country, but they are also good with the use of speech because they have to manage their properties and the people who work for them. In a political reading of the tragedy, Foucault explains that the autourgos would represent the conservative party, whereas the first represent the interests of the democrats.

For the first time, a matter is introduced that had not appeared before, which is the matter of mathesis, that is, education and knowledge. Parrhesia appears here as something that cannot solely be the pure liberty of speech given to any citizen, but that in order to make good use of this speaking freely in favour of the city, it is necessary to have a good education, intellectual and moral instruction, a paideia or a mathēsis, and only by occurring in this way will he be anything other than mere noise, a thorubos, and be able to have positive effects for the city. It is interesting to analyze that this need to care for oneself is represented in the character of the yeoman, the autourgos, who is characterized as the person who cultivates the land for himself, with his own hands, and it can be read as the person who cultivates himself.

The principle of inequality is thus introduced. As a consequence, if parrhesia was the right to speak of any Athenian citizen, and we have already seen that in the tragedy of Ion the truth of the slave, the chorus and Ion corresponded, this 
truth is remade with fragments of the discourses of all the citizens, regardless of their social class or access to education. It is a truth that still corresponds to the symbolic truth, that is, a single truth common to all. However, here a change is introduced that will dismantle the very concept of parrhesia. Because, as we have seen, parrhesia emerges associated with isegoria and isonomia through the person who speaks, through their identity (who is Oedipus, who is Ion). But now there is a distinction between good and bad parrhesia. The latter corresponds to formal parrhesia, exercized by those people who make use of this right without a suitable education (mathēsis). The use of parrhesia therefore introduces disagreement and debate. Parrhesia does not respond to the discursive strategy capable of reaching one sole truth that is common to everyone, but, quite the opposite, it seems to introduce disparity and plural fragmentation of a truth that will no longer be symbolic.

The complexity increases when, moreover, the violence of the discourse that is exercized through force - defined as an extreme opinion that causes unanimity - is in contrast to the restraint of the yeoman parrhesiast, who argues from the conviction of reasoning and yet can be less effective: "you can see that if the bad parrhesia is associated with violence and passion, then the good one is linked with mathēsis" (108).

Lastly, this problematization culminates in a difficulty in giving a voice to all citizens, and the distinction between good and bad parrhesia corresponds with the social division between those that should govern and those that, not having the appropriate education, should be governed.

From the point of view of the history of parrhesia, Foucault says, Orestes represents the shift from the golden age of political parrhesia, that ten years earlier had been represented in Ion (418 BCE), to the problematization of parrhesia. The parrhesia in Ion had a clearly positive value: it was a freedom or privilege that any citizen who wished could enjoy, and when they needed it. It was a question of the type of right that some citizens, the first citizens, could make use of; and when they made use of that parrhesia, they said what they thought and, at the same time, this was true, because they were well born and maintained a certain type of relation with the city, the law, and the truth. Thus there was no problematization of the relation with the truth in this first description of parrhesia, but for the metaphor of the drop of Gorgon blood. But Orestes represents the problematization of parrhesia, and the question of who is fit for government due to their status or their personal qualities. The first problem calls into question the correlation between parrhesia and isegoria: 
There is a discrepancy between an egalitarian system which enables everyone to use parrhesia, and the necessity of choosing among the citizenry those who are able (because of their social or personal qualities) to use parrhesia in such a way that it truly benefits the city.

And the second problem is the problem of education, of mathēsis as education and knowledge. This means that at the moment in which Orestes is staged, parrhesia was being questioned as an activity capable of revealing the truth by itself. In order to exercise parrhesia suitably, some form of education is needed, nor merely the courage to speak frankly. But, more specifically, it requires personal training.

Therefore, Orestes shows how, at the end of the fifth century BCE, Athens was undergoing this problematization of parrhesia, that "frank speech" could no longer be granted to all citizens. We can see that here we find a key moment in the relations between freedom, power and knowledge/truth in the origin of democracy, a beginning of social and epistemological separation, which distinguishes between those who make good use of speech and those who are not capable because their discourse is confused with uproar. Therefore, the problematization refers to two aspects that had formed the first parrhesia in an undifferentiated way: equality and the relation with the truth.

In the other play that Foucault uses to refer to the heralds, The Trojan Women, this character is in contrast to another figure of veridiction, the inspired and barely believable Cassandra. The tragedy shows us one more trait of the herald: in their relation with veridiction, the are incapable of distinguishing what is true. In the scene, Cassandra foresees the death of Agamemnon, and the herald, Talthybius, does not believe her, and declares that she is mad: "Ouk artias echeis phrenas (your mind is not in the right place)" (102). Cassandra replies: "Keen-witted varlet this! Why such fair name have heralds, common loathing of mankind, who are but menials of kings and cities." She goes on and explains: "you have said that my mother will become Odysseus' slave, but in fact the gods have said that she will die here," and it is the truth. Thus the herald is someone who cannot know the truth, who is incapable of saying the truth, of recognizing it, insofar as he is dependent on another, on his master. As the herald of Agamemnon, Talthybius does not believe in the words of Cassandra, because he must say what his master has told him to say. This means that he speaks under a certain coercion: "You see, the herald is one who cannot know the truth, who is unable to tell the truth, or to recognize the truth, insofar as he is dependent on someone else, that is, on his master" (102). The same thing happened in Orestes, in which the yeoman (autourgos), despite speaking with parrhesia, does not manage to convince the crowd. This is, undoubtedly, a critique of the persuasive use of discourse compared to the frank speech of parrhesia. 
This same game of oppositions can be found in the case of Cassandra in The Trojan Women, a character who, for Critchley, represents the impossibility of affective communication: "Cassandra sees the truth clearly and accurately but cannot persuade anyone to believe her. There seems to be a persistent, performative gap between truth and persuasion" (Critchley, Tragedy, the Greeks, and Us, 116).

But Euripides's Cassandra is already a problematic character. The evolution of Cassandra as a mythological character from Aeschylus to Euripides sets us on the trail of this problematization and its relation with parrhesia. Because, although in Aeschylus's Agamemnon Cassandra is described as a prophet, in Euripides she represents the loss of communication with the world of the gods. As Nietzsche warned in The Birth of Tragedy, Euripides brings a distant mythological world closer to daily reality: "Through him the common man found his way from the auditorium onto the stage. That mirror, which previously had shown only the great and bold features, now took on the kind of accuracy that reflects also the paltry traits of nature [...] People themselves learned to speak from Euripides" (Nietzsche, The Birth of Tragedy, 211).

Cassandra is a controversial character because in her are brought together traits of the parrhesiastes and another form of veridiction typical of seers, but whose relationship with the gods is not direct. On the one hand, Cassandra possesses traits of "prophetic madness", as per the classification that Plato makes in Phaedrus. But Talthybius, Agamemnon's herald, describes her as a maenad, priestess of Dionysus, and not as a seer or mantis, as she is called in Aeschylus's Agamemnon. Eric Robertson Dodds explains in his classic work, The Greeks and the Irrational (1951), that the Greeks already distinguished between inspired or divine madness and madness as illness. Talthybius describes Cassandra as driven mad, that she is no longer of sane mind. Thus the scene between Cassandra parrhesiastic figure who combines inspiration and human veridiction - and Talthybius, the herald, represents the confusion between divine, inspired madness and madness as mental illness.

As a parrhesiastic figure, Cassandra shows another trait of classical truth: the confusion of her truth with mental illness and, in addition, the loss of the unitary truth of the gods. This is because, remember, the character of Cassandra tells the truth, but the keys to comprehending her truth-telling have been lost because she is no longer connected to the divine, insomuch as she has resisted submitting to the god Apollo. Her continuation to tell the truth is proof, therefore, of her resistance. But, in turn, this disconnection from the truth of divine authority has the consequence that Apollo inflicts the punishment on her of not being understood, that her truth will no longer be shared among her own people. Because Cassandra does not speak as a priestess enlightened by a god and, 
therefore, the truth of Cassandra no longer forms part of that magnetic chain described by Plato in Ion. She has broken the chain and tells a truth that does not connect, and the sense that it is not seductive, it does not persuade. And because of this, she represents a speech that is wholly opposite to the speech of Helen. Therefore, in Foucault's focus on the truth pronounced by Cassandra, he again stresses that the truth is not concerned with persuasion, but with an emancipatory speech with performative consequences.

Furthermore, Foucault again emphasises that parrhesia involves an emancipatory speech that projects its consequences onto specific historical moments. Parrhesia enables Foucault to move a step ahead of the ethics of the care of self to the radically political origin of the constitution of subjectivity. It is by going to the origin of Greek democracy that Foucault finds the story of the self as the political configuration of the demos. As he stated in 1977 in the Collège de France lecture, "Security, Territory, Population", the dimension of what must be made can only be manifested in a "field of real forces" that "cannot be created by a speaking subject alone".

And Talthybius the herald does not believe Cassandra's predictions because "as a herald, [he] must say what his master tells him to say" (Foucault, Discourse and Truth and Parrhesia, 102). Indeed, the herald is incapable of speaking and recognizing the truth, insofar as he is not a free person, he is a citizen chained to his lord and is restricted to repeat what his master has told him to say. Hence, Foucault explains, he believes that Cassandra is mad. The herald is an unemancipated character, subjected on a political level to epistemological consequences.

After the crisis of parrhesia described through the analysis of these characters, we see an immediate consequence: equality is conditioned by paideia or mathēsis, according to the term used in Orestes by Euripides. And, in this way, a correlation between parrhesia and the care of the self is established, the ethical foundation of political freedom. In order to develop equality and the government of others, one must cultivate oneself, as the road to emancipation and to the exercise of critical thought necessary for democracy.

Christoph Menke has developed this argument in Force: A Fundamental Concept of Aesthetic Anthropology. He considers that for the citizen to develop an equality, which it only is in potential, a paideia is needed, and that this transformation is possible as an exercise of the aesthetics of self. In Rancière, however, equality is an a priori in order to think the distribution of the sensible. And Foucault problematizes the concept of democracy by associating its birth with the problematization of the very concepts that sustain it: isegoria and isonomia. 
In the lecture held on $2^{\text {nd }}$ February 1983, of the series The Government of Self and Others, Foucault stated that parrhesia was born with democracy; but what he also says is that it is separated from democracy after its historical problematization. Parrhesia was already a problematic concept from its formation, due to the contradiction between the elements that form it or the four corners of a square of parrhesia: democracy as freedom (formal condition), the government of a few (condition of fact), speaking the rational truth (condition of truth), and courage, struggle (condition of morality). Therefore, there is already a principle of division between those who make good use of speech and those who do not. It is the arduous problem concerning who should govern. And Foucault says that Euripides (conservative and realist) does not problematize the concept while he who makes use of it is privileged, like Ion; but Orestes is a different case, which shows how someone who is not autochthonous and who represents the interests of the democrats, as opposed to the aristocrats, seems to utter only shouts and not arguments, parrhesia is not recognized for him. So we see how the use of rhetoric in Euripides articulates a criticism of parrhesia, and more fundamentally, of isegoria. Against the criticism of those who appear to utter only shouts and not arguments, Foucault argues that what he wanted to reply is that nobody, even though they are athuroglōssos, speaks in order to not say anything. Verbal activity is always a response to a certain situation. But parrhesia seems to become a doubleedged weapon, given that it can be used as "bad parrhesia" against democracy itself, because it can be used by dangerous citizens who can lead democracy into crisis or tyranny: "And, on the other side, since parrēsia is given even to the worst citizens, isn't it a fact that this parrhesia becomes a danger for the city and for democracy itself, since the overwhelming influence of bad orators leads necessarily to tyranny?" (Foucault, Discourse and Truth and Parrhesia, 124). In this way, the parrhesiastes is no longer appreciated as a necessary character for democracy and the assembly government, but rather as a danger or a double truth. It is, in short, the step from parrhesia to the pharmacy.

Subsequently, parrhesia, as frank speech that determines both the care of others (government) and the care of oneself, is inserted into the tradition of Christianity. As Werner Jaeger explains in Early Christianity and Greek Paideia (1961), "with the Greek language a whole world of concepts, categories of thought, inherited metaphors, and subtle connotations of meaning enters Christian thought" (6). Therefore, after the disappearance of the term in tragedy, parrhesia reappears in the texts of John Chrysostom. 


\subsection{From Ancient Tragedy to Modern Narrative: Literature as Critique}

As we have seen, the problematization of parrhesia entails fundamental consequences. On the one hand, parrhesia ceases to be tied to democracy and undergoes a broad and varied development in different movements from Greek thought through to Christianity. On the other hand, the critique of parrhesia at the heart of democracy leads to the negation of isegoria and isonomia, and to the resulting social division that is associated, in turn, with the division of rational discourse - the insane are banned from Assemblies - as well as all those who make use of discourse lacking in reason because it resembles shouting which are, ultimately, those who make it impossible to agree on $a$ truth. And, lastly, this crisis of democracy demands a replacement: mathēsis or paideia, which Foucault analyzes through the technologies of the self, which are developed in the West from the classical era and whose consequences reach the present day, above all through the legacy of the Cynics.

These three dimensions of the problematization of parrhesia find a clear echo in the work of Foucault as critique. On the one hand, the studies on madness are a constant and at the end of his work, they come together in his project of seeking "potential modes of existence for possible subjects" (Foucault, The Government of Self and Others, 3). Madness is therefore considered a matrix of knowledge on the phenomena of deviation within a society. And the social partitioning of madness means the introduction of technologies by means of which it is aimed to drive the behaviour of others (3-4). However, these strategies of domination of subjectivities emphasize the possibility itself of the transformation of the subject and, consequently, they in their turn make possible technologies of resistance and of the constitution of subjects. ${ }^{45}$

This leads Foucault to recognize in the Kantian Aufklärung the legacy of classical parrhesia in modernity. Foucault's interest in Kant's "Was ist Aufklärung?" appears repeatedly from 1978 ("What is Critique?") until the end of his life. ${ }^{46}$ And

45 Along these lines, we can understand the reading that Diogenes makes of Oedipus Rex. According to Diogenes, the problem of Oedipus is not that his fate is marked by the gods, but that he is of human origin: Oedipus errs in the interpretation of the signs of the oracle, just as his father Laius also does. But in the case of Oedipus, says Diogenes, the gravest error was not doing things himself but to delegate to others (The Courage of the Truth). The process of emancipation of the subject begins with one's work on oneself, as had already been represented in the figure of the yeoman in the Orestes.

46 The same meeting between J. Habermas and M. Foucault in UC Berkeley, that did not happen due to Foucault's death in 1984, was due to be a reflection on Kant's text. 
the ethical-political shift in Foucault's work can be read in line with Kant's proposal. In Kant, we find a new relation between morality and politics, ${ }^{47}$ between will and the common state of well-being, which coincides with Foucault's approach.

The Aufklärung is defined by Kant as “man's emergence from his selfincurred immaturity", understanding this immaturity as "inability to use one's own understanding without the guidance of another" because "its cause is not lack of understanding, but lack of resolution and courage to use it without the guidance of another". Therefore, the Sapere aude! describes the parrhesiastic interpellation of "dare to be wise", the "courage to use your own understanding”. In short, the distinction between governed and governors is not natural, it is not attributed to the capacities of citizens and, for this reason, we can conclude, every person is responsible for their own emancipation and resistance.

The common forms of resistance belong, therefore, to the experience and the tradition that begins with the parrhesia of the Cynics, and they are expressed in the modes of life as resistance, that is, in "the art of life" as "militantism". This aesthetics of existence to which Foucault devotes much of his investigation in History of Sexuality, and his Collège de France lectures, in particular, The Courage of the Truth. Life is, therefore, a stage for revolutionary activity, "or revolutionary activity as life". Foucault recognizes three forms of militantism of experience: the secret society, trade unions or political organizations with revolutionary ends, and, third, which Foucault gives special attention, "militancy as bearing witness by one's life", which should break with the conventions, habits and values of society, which highlights the possibility of living in another way to the socially admitted as scandalous life, "the scandal of the revolutionary life" as true life and which, in general terms, Foucault points out in the mid-nineteenth century (Foucault, The Courage of the Truth, 185-6).

Along with this vehicle of Cynicism or the theme of the mode of life as scandal of the truth, Foucault points out a third way - art. Not only as a form that gives an account of this aesthetic of life, as is Russian nihilism in the literature of Dostoyevsky, ${ }^{48}$ but as Cynical literature, habitual in the satire and comedy of

47 Politics concerns itself in the action of a state, of a group, whereas morality concerns itself with personal decisions, with free will, to act in a certain way.

48 By way of example, in Dosteyevsky's The Idiot the relation with parrhesia is established, firstly, in the character of Prince Myshkin, who is also inserted into the tradition of the parrhesiastes: a character with an education between autodidacticism and pedagogical experimentation, he is catalogued throughout the novel as: ill, artist, philosopher, mad, idiot, and democrat. Myshkin is the character who is not afraid to say everything and who is identified with his speech. Secondly, parrhesia is presented in the structure of the novel itself. As 
medieval and Christian Europe and in the carnivalesque literature Bakhtin mentions:

The fabliaux would no doubt belong to this domain, as well as the literature studied by Bakhtin, who relates it particularly to the festival and carnival, but which I think also certainly falls under this manifestation of the Cynic life: the problem of the relations between the festival and the Cynic life (naked, violent life, the life which scandalously manifests the truth). We would again come across many of the themes concerning the carnival and carnivalesque practice.

(Foucault, The Courage of the Truth, 187)

However, the question of Cynicism reaches even modern art, where it is of singular importance, according to Foucault. This legacy of Cynicism of the aesthetic of existence (the bond between life and truth), reaches us in two ways: its appearance in Europe at the beginning of modernity, of "the life of the artist”, which was not completely new, but that acquires original importance:

the modern idea that the artist's life, in the very form it takes, should constitute some kind of testimony of what art is in its truth. The artist's life must not only be sufficiently singular for him to be able to create his work, but it must in some way be a manifestation of art itself in its truth.

This modern idea of the artist's life is based on two principles: art is capable of giving existence to a form that breaks, a breaking as the truth of life; and life is the guarantee that every work that takes root in this life and begins from it, belongs to art. This is to say, it is the life of the artist that makes it possible for the work itself to be manifested as truth, a truth, as we have said, that is scandalous, that breaks from the past and is revolutionary. And it is what, as per Foucault, leads us to the second reason why art is the vehicle of the Cynical aesthetic of existence. This is the idea that the relation of literature with the real is one of laying bare, of unmasking. We find this idea, Foucault says, in the literature of Baudelaire and Flaubert, as the place of the event of what is elemental of life. This violent gesture that modern literature exercises upon reality is anti-Platonic and anti-Aristotelian at the same time, because it is "the endless movement by

Bakhtin described in Problems of Dostoevsky's Poetics, it is a polyphonic novel that breaks from the organic structure of the body of unitary text. Myshkin himself is criticized for his "unbalanced" dialogue, as critique of the anti-Aristotelian composition of the work: "A plurality of independent and unmerged voices and consciousnesses, a genuine polyphony of fully valid voices is in fact the chief characteristic of Dostoyevsky's novels. What unfolds in his works is not a multitude of characters and fates in a single objective world, illuminated by a single authorial consciousness" (6). 
which every rule laid down, deduced, induced, or inferred from preceding actions is rejected and refused by the following action" (188). Literature has, therefore, a function of criticism through its anti-cultural nature, because, faced with the consensus of culture, art confronts the courage of "its barbaric truth", which is, remember, the possibility of dissent. Modern art, Foucault says, above all has the courage to run the risk of "offending”. And its capacity to criticise is inherited from Cynicism, which comes to literature via the Sceptic style and nihilism of the nineteenth century (189). For Foucault, the "question of nihilism is not: if God does not exist, everything is permitted. Its formula is rather a question: how to live if I must face up to the fact that 'nothing is true'?" (190). ${ }^{49}$

In the Western history of truth, in which there have been different and diverse truths, Foucault says:

In this West, which has invented many different truths and fashioned so many arts of existence, Cynicism constantly reminds us that very little truth is indispensable for whoever wishes to live truly and that very little life is needed when one truly holds to the truth.

Lastly, I would like to go back to the question of the legacy of parrhesia in modern literature. I consider that, as well as the development of the aesthetic of existence as a central theme of the modern literary opus, parrhesia has reached modern literature in its status of discourse and in its anti-Aristotelian and antiPlatonic form. Parrhesia had traced a discontinuous line in relation to unreason, Euripidean tragedy and modern literature, projecting its political dimension upon it. Thus this language, as deviation from the language of instrumental reason, is also the language of unreason. It takes up, in a different way, the relation between literature and madness.

Parrhesia reaches literary forms through the Cynical legacy of the genres of comedy and carnivalesque literature, until arriving at the modern novel. We can consider that the relation between parrhesia and the modern polyphonic novel is a broad one. The basis of this hypothesis lies, on the one hand, in Menippean satire's derivation from Socratic dialogue; and, on the other hand, it is found in the transformation of parrhesia in Cynic philosophy as a way of life, as I have already described. Bakhtin himself had already highlighted Menippean satire from among the tragi-comic genres of classical antiquity that would prepare the way for the carnivalesque view of the world and of the modern dialogic novel in Problems of Dostoevsky's Poetics. However, the modern novel had also inherited elements from classical Euripidean tragedy, as

49 Here we can see the work that Foucault did on Sade, to which I have referred in Chapter 3. 
democratic speech. ${ }^{50}$ If, as Christoph Menke states, the content of experience of tragedy is "tragic irony", that is, the tragic experience of action is that in which an action aimed at achieving an objective fails, then we can declare that, beyond modern theatre, we find elements inherited from classical tragedy in the modern polyphonic novel. That configuration using an accumulation of partial views is, also, one of the fundamental traits described by Bakhtin and Rancière in their description of the polyphonic novel and democratic novel, respectively.

As Michael Hardt and Antonio Negri remind us in their definition of "multitude", dialogic novels are presented as democratic models that overcome the modern alternative between sovereignty and anarchy:

For him [Bakhtin] these limits directly betray the fact that it is impossible to construct a world in which each subject is not based on its recognition of others. This is where it becomes clear why Bakhtin conducts this polemic with reference to Dostoyevsky's novels, because in Dostoyevsky, he explains, narration is always dialogical, even between the protagonist and his cat. [...] Dostoyevsky's novels are thus great polyphonic apparatuses that create a world in which an open, expansive set of subjects internet and seek happiness.

(Hardt \& Negri, Multitude, 208)

Therefore, the legacy of the tradition of literature and parrhesia, and Bakhtin's conception of modern literature, coincide in that they oppose the norms of representative poetics, the indifference of form with regard to its content. And they oppose the idea of fiction-poetry, that of poetry as proper mode of language. Both principles oppose the mimesis of the word in act, a specific art of writing. The concept of writing in Foucault is particularly close to Rancière's. For Rancière and Foucault, writing and literature share their contradictory character, "it can be orphaned speech lacking a body that might accompany it and attest to it, or, on the contrary, it can be a hieroglyph that bears its idea upon its body" (Rancière, Mute Speech, 36). To this contradictory character of writing, Foucault adds a performative dimension that we find in his concept of literature, and which is another of the fundamental traits of parrhesia.

50 For the development of this issue, I refer to the first part of Nietzsche's classic text, "Socrates and Greek Tragedy". Here, Nietzsche underlined that with Euripides the spectator attended theatre to see man in the reality of daily life - the spectator saw his own double. Thus the people learned to speak and language was made understandable and understood by all. "His heroes really are as they talk. But they also express all that they are, while the Aeschylean and Sophoclean characters are more profound and complete than their words: they only babble about themselves." 
The multitude of democracy, as in its Greek origins, is founded on the lack of distinction between the masses and the group of the few, in the opening of all the discourses in the assembly, in the beginning of equality. Literature as the text of historical becoming, as event, is a truth-telling as excess, as parrhesiastic speech, which puts the seriousness of the genre itself in danger. ${ }^{51}$ Literature dares to "say everything".

Finally, polyphonic literature, as a form of evental veridiction of a community, offers a space of resistance against police power, characterized by determining the behavior and freedom of other men. Literature inherited from parrhesia its capacity to say everything, and to resist the forms of political rationalization. Thus, the modern novel has inherited its political consequences from parrhesia, from its excessive and undifferentiated speech. Modern literature entails the end of representative order, not its apex, precisely due to the excessive speech of the modern novel. The excess in the modern novel's speech is the opposition of an everything to another. It marks the ruin of an everything that was in harmony with the stability of the social body. Because of this, parrhesia is critical discourse that is inserted into modern literature. Recalling the text quoted from Constitution of the Athenians, parrhesia is founded on the lack of distinction between the masses and the group of the few, in the opening of all the discourses in the assembly, or the principle of equality.

51 In binary opposition with philosophy, literature traditionally occupies the place of what is not serious. 